\title{
O poder do povo no Federalista: virtude e vontade na República Federativa dos Estados Unidos da América de acordo com Hamilton, Madison e Jay
}

Felipe Augusto Mariano Pires ${ }^{1}$

1 Graduação em Filosofia (Bacherelado e Licenciatura) pela UFPE. Mestrado em Filosofia pela UFPE. Professor Assistente da UFERSA - Universidade Federal Rural do Semi-Árido, no Departamento de Ciência e Tecnologia.

E-mail: nitrorhiso@hotmail.com

RESUMO: Com este trabalho, buscamos verificar o quanto de poder o povo possui na forma de governo defendida no Federalista em relação ao direcionamento do governo para os seus fins. Para isso, buscamos entender o papel dos conceitos de virtude e vontade na referida forma de governo e a relação de tais conceitos com o poder. Utilizamos como pano de fundo as ideias de Locke, Montesquieu e Rousseau sobre representação. Concluímos que o Federalista se contrapõe a Rousseau e segue Montesquieu, trazendo de volta a virtude como elemento principal de condução do governo aos seus fins, separando o povo dos governantes, que formariam agora uma classe profissional, e fazendo a substituição do cidadão para o homem ligado ao comércio e à vida privada.

Palavras-chave: O Federalista. Poder. Povo.

ABSTRACT: With this work, we seek to verify how much power people have in the form of government defended by the Federalist Papers in relation to the direction of governmento for its ends. For this we seek to understand the concept's role of virtue and will in the referred form of government and the relation of these concepts with power. We used as a background the ideas of Locke, Montesquieu and Rousseau on representation. We concluded that the Federalist Papers is opposed to Rousseau and follows Montesquieu, bringing back virtue as the main element of the conduction of government to its ends, separating the people from rulers, who would now form a professional class, and making the substitution of the citizen for the man linked to trade and private life.

Keywords: Federalist Papers. Power. People.

\section{INTRODUÇÃO}

O que contemporaneamente chamamos democracia, a democracia representativa, vive um impasse, uma verdadeira crise da ideia de representação. Singer (2000), baseado em Giddens ${ }^{1}$, explica isso através do paradoxo de que, ao mesmo tempo em que a democracia se espalha pelo mundo, aquelas democracias mais maduras, as que são copiadas, experimentam hoje um enorme descrédito em relação aos seus processos. Segundo o Singer, a situação seria mais grave na América Latina, onde a democracia nem chegou a se consolidar e a desilusão já chegou.

Diante desse problema, Singer aponta para duas obras do século XVIII, a saber, o Contrato Social, de Jean-Jacques Rousseau (1973), e O Federalista, de Madison, Hamilton e Jay (HAMILTON et al., 1973). Ele busca um terreno comum entre as duas obras, apostando que, neste, haveria pistas para encontrar a solução,

${ }^{1}$ Anthony Giddens (GIDDENS, 2000). 
com uma combinação entre participação direta local e representação nas unidades políticas mais amplas.

A escolha dessas duas obras se deve a posições bem antagônicas entre as mesmas. Rousseau foi um grande crítico da representação no seu livro Do Contrato Social (1973), sendo ainda hoje uma das principais referências na questão da defesa da necessidade de participação do povo nos rumos do governo. Já O Federalista (HAMILTON et al., 1973) traz uma teoria política dita democrática, nas palavras do próprio Singer², "que visa evitar os abusos do poder da maioria e, por isso, enxerga o governo como necessariamente descolado do povo" (SINGER, 2000, p. 42). O cientista político vê como pontos de contato entre as obras o objetivo de estabelecer uma soberania imanente, nascida do povo, e o perigo do seu sequestro, pelos representantes ou pela maioria da assembleia.

Discordamos (humildemente) do caminho seguido por Singer ${ }^{3}$, pelo fato de considerarmos o terreno comum entre as duas obras apenas as questões envolvidas e os temas discutidos - que, em grande medida, achamos ser um reflexo da divulgação da obra e dos argumentos de Rousseau, que apareciam nos textos Anti-Federalistas ${ }^{4}$ - e não as soluções. Os dois livros não possuem um terreno comum em relação às suas ideias do que seria um bom governo. São, na verdade, muito opostos em seus intentos.

Em trabalhos anteriores ${ }^{5}$, fizemos a observação de que o trabalho de Rousseau incorpora todas as principais tendências da modernidade no que diz respeito à ética e à política, em especial a ideia de que o poder, o direcionamento do governo, deixaria de ser um assunto exclusivo para os virtuosos e passaria a ser exercido pelo povo, todo o povo. A ideia de representação legislativa significava para Rousseau o mesmo que a usurpação da liberdade e da igualdade dos homens, o domínio de uma classe sobre o povo. A principal ideia do Contrato Social (1973), a nosso ver, é que povo no poder é o princípio através do qual se pode definir a legitimidade de um governo.

O Federalista (HAMILTON et al., 1973), por sua vez, é conhecido como uma janela privilegiada, a principal delas, para o pensamento que deu origem à Constituição dos Estados Unidos da América. A coleção de artigos visava convencer os norte-americanos a votarem a favor da nova Constituição no plebiscito organizado para isso e seus argumentos respondem principalmente as críticas à Constituição levantadas por pessoas que vieram a ser conhecidas como os "Anti-Federalistas". Contudo, o Federalista se insere em uma discussão maior da filosofia política, a do surgimento do que conhecemos por democracia moderna, tendo como pano de fundo da discussão os grandes clássicos da filosofia política, e a importância desta coleção de artigos para a história da filosofia política consiste exatamente no fato de que a referida Constituição marca um dos principais moldes com os quais foi construída o que chamamos de democracia nos dias de hoje, cuja principal característica é a representação através de um parlamento. No caso do Brasil, o Federalista assume uma importância maior, pois a Constituição Brasileira recebeu uma especial influência da Constituição Norte-Americana, adotando uma forma de governo bem semelhante.

Em relação à história da filosofia política, o Federalista, mesmo que não seja um livro nos moldes mais usuais deste ramo do conhecimento, não deixa de pertencer a este e até mesmo avança em determinadas questões, como a do próprio federalismo, a da divisão dos poderes e a dos freios e contrapesos. Os 85 textos de Madison, Hamilton e Jay se encontram em um ponto de grande interesse para nós na pesquisa sobre o

2 Um pouco mais à frente, neste trabalho, veremos que os autores do Federalista não consideravam a forma de governo dos E.U.A. como uma democracia.

3 Sem querer, de nenhum modo, desmerecer o estudioso em questão e reconhecendo a qualidade do seu trabalho.

${ }^{4}$ De acordo com Miller (1988), o movimento Anti-Federalista deve ser entendida dentro do contexto da cultura política democrática do século XVIII, tendo como elementos essenciais comunidades pequenas e participativas, governos simples locais, participação popular direta, entre outros. Contudo, o tema merece um estudo mais aprofundado.

5 Sobre isso, consultar PIRES, 2015. 
surgimento da forma de governo que hoje é o modelo daquilo que chamamos democracia, a democracia representativa, tendo recebido uma grande influência de Montesquieu (1979) e, apesar de não haver declarações explícitas, sendo um forte antagonista ao pensamento político de Rousseau (1973).

A nossa abordagem do Federalista (HAMILTON et al., 1973) tem como enfoque o quantum de poder do povo sob a Constituição que é defendida, a saber, a possibilidade que o povo tem de ditar os rumos do governo. Para isso, veremos os artigos em questão através da teoria das formas de governo, observando quais papéis desempenham a virtude e a vontade no governo considerado bom pelos autores e retirando, a partir disso, conclusões a respeito deste tema. As perguntas a serem feitas são: o quanto a vontade do povo influi nos rumos do governo defendido? E qual a relação da virtude com a participação do povo no poder?

É certo que o Federalista não desenvolve uma teoria das formas de governo completa, como o fazem os grandes clássicos da filosofia política, mas ele nos dá o principal para a nossa empreitada: a forma de governo considerada a melhor, defendida pelos autores, de onde nós veremos o quanto de participação o povo possui, e as formas contra as quais aquela considerada boa busca evitar.

Como contextualização, escolhemos confrontar o Federalista com os principais clássicos da filosofia política moderna que tratam sobre representação, notadamente Locke (2001), Montesquieu (1979) e Rousseau (1973), deixando um movimento Anti-Federalista para um trabalho futuro.

\section{LOCKE E MONTESQUIEU: DOIS DEFENSORES DA REPRESENTAÇÃO}

Tanto Locke (2001) quanto Montesquieu (1979) defenderam a representação em suas teorias políticas, contrariando as principais tendências da modernidade em relação à ética e à política. Nesses autores, a representação significou, a nosso ver, um passo atrás na defesa de um governo dirigido pela vontade do povo e uma reinserção disfarçada do argumento da virtude. Pelo menos, temos que crer que tais autores não quiseram atingir as consequências necessárias dos princípios que sustentavam.

Expusemos em trabalho anterior (PIRES, 2015) que as mudanças da Antiguidade à Modernidade seguiram tendências como a mudança da diferença natural à igualdade natural do homem, da liberdade para poucos à liberdade natural como direito natural, da pólis hierarquizada à igualdade no Estado, do naturalismo ao anti-naturalismo do Estado, da centralidade da virtude à centralidade da vontade na condução dos destinos do governo, da polis como organismo à máquina política, da virtude como disposição de caráter (de alma) à virtude para todos, etc. Este passo atrás dado pela ideia de representação começa de uma forma escorregadia em Locke (2001), mas torna-se explícito em Montesquieu (1979), ou seja, a reinserção da ideia de que apenas os virtuosos devem fazer leis e governar.

Locke, em seu Segundo Tratado Sobre o Governo Civil (2001), afirma que o Estado surge a partir do pacto social, que vem retirar os homens de um estado de insegurança e colocá-los sob uma lei comum a todos, e que aquilo que conduz o Estado à sua finalidade é a vontade do povo, identificada por ele como a determinação da maioria, ou seja, a maioria teria o direito de decidir pelo todo.

Estando os homens unidos em um só corpo, sob governo, leis e sistema judiciário comum a todos, surgem os poderes legislativo e executivo. As leis, segundo Locke, devem vir da vontade do povo. O legislativo pertence ao povo e está acima dos outros poderes. Contudo, Locke afirma que a vontade do povo pode $^{6}$ ser expressa através de representantes, que seriam eleitos pelo povo e voltariam à condição de súditos

${ }^{6}$ Aqui é importante frisar bem o termo "pode", que ainda não é "deve". Ou seja, em Locke, a representação é colocada como uma opção ao poder direto do povo no legislativo, uma opção que não traria prejuízo ao próprio povo. Isso traz consigo uma ambiguidade: primeiro, existe a possibilidade da participação direta do povo no legislativo, esse seria o 
logo após terem elaborado as leis.

As formas de governo em Locke baseiam-se em relação a quem é entregue o legislativo, havendo monarquia se entregue a um homem, oligarquia quando entregue a um grupo selecionado e a democracia quando a maioria o ocupa. Em relação à melhor forma de governo, Locke, a nosso ver, deveria apontar para o que ele mesmo chama a democracia perfeita, que é o legislativo em poder da maioria, mas, contrariamente, aponta para uma forma representativa, com o legislativo composto de assembleias de composição variável em que os legisladores voltam à condição de súditos assim que encerram a elaboração das leis. Em suma, o modelo de legislativo apontado por Locke é este: representantes eleitos pelo povo, vindos do próprio corpo político, unidos numa assembleia legislativa temporária para a elaboração das leis e que voltam à condição de súditos assim que termina o trabalho, salientando que a convocação e a duração da assembleia são prerrogativas do executivo.

Podemos perceber que Locke, que havia afirmado que quem deve dirigir o rumo do governo é a vontade do povo, insere um sistema representativo como melhor forma de governo sem maiores justificações. Já Montesquieu (1979) dirá claramente os motivos que o levam a isso. É importante salientar que a representação em Locke (2001) é muito diferente da que temos nas democracias dos dias atuais; no filósofo britânico, os representantes não seriam políticos profissionais, por voltarem à condição de cidadão assim que se desse o término da elaboração das leis, e não atenderiam a interesses de facções, já que seriam eles mesmos cidadãos comuns, eleitos pela maioria do povo.

Montesquieu, no Espírito das Leis (1979), por sua vez, apesar de não ser um autor contratualista, afirma que as leis positivas são decorrência do estado de guerra e que o Estado surge da união de todas as forças individuais, formando uma força geral que pode ser colocada a cargo de um ou de muitos homens. Ele começa a sua teoria das formas de governo afirmando que cada povo teria uma forma de governo mais adequada para si de acordo com a sua natureza e as suas leis particulares, em uma relação natureza-governoleis particulares. $\mathrm{Na}$ república, o poder soberano pertence ou ao povo todo, caso em que teríamos a democracia, ou a uma parte do povo, caso da aristocracia. Na monarquia, o poder pertence a apenas um. No despotismo, o poder também pertence a um, mas sem obedecer a leis ou regras.

$\mathrm{Na}$ sua argumentação sobre a democracia, Montesquieu vai abrir caminho para a sua defesa da representação. Ele afirma que, nesta forma de governo, o povo governa por sufrágios. O soberano é a vontade do soberano, ou seja, a vontade do povo. Contudo, é aqui que Montesquieu inicia suas ressalvas, dizendo que o povo não pode realizar tudo. Logo, o povo deveria realizar apenas aquilo que é capaz de fazer corretamente, deixando aquilo que não consegue para ministros ou magistrados. Além disso, o povo teria a necessidade de ser conduzido por um conselho ou senado, eleito pelo povo ou pelos magistrados. Para o autor do Espirito das Leis, o povo sabe escolher aqueles a quem confiar parte da sua autoridade, mas não sabe "dirigir um negócio, conhecer os lugares, as ocasiões, os momentos e aproveitá-los" (MONTESQUIEU, 1979, p. 32; II, II). Ou seja, é a volta, dentro da argumentação da vontade do povo no poder, do argumento da tirania do povo, que afirma que o povo, deixado a si mesmo, por sua falta de virtude, torna-se tirano de si mesmo. Vimos em Locke (2001) uma preferência pelo modelo representativo, mas Montesquieu (1979), em nossa opinião, mantém mais firmemente a reticência em relação aos destinos que o povo pode dar ao Estado. Ou seja, o soberano é a vontade do povo, mas tal vontade precisa ser esclarecida, segundo ele, por “certos personagens” (MONTESQUIEU, 1979, p. 33; II, II).

ponto de origem; segundo, há uma opção sem prejuízos, que, no fim das contas, Locke aponta como a melhor, sem muita explicação. 
Para Montesquieu, na democracia, é preciso saber dividir o povo em certas classes, que dizem respeito ao direito de sufrágio. Como dar o direito ao voto? O sorteio é da natureza da democracia, assim como a escolha é da aristocracia, mas o sorteio é uma forma defeituosa, o que deve ser corrigido, segundo Montesquieu, pela adoção dos votos públicos (entenda-se voto aberto mesmo), para que "a plebe seja esclarecida pelos principais e contida pela seriedade de certos personagens” (MONTESQUIEU, 1979, p. 33; II, II).

Saindo das descrições sobre as formas de governo, entramos agora num assunto de grande importância no pensamento político moderno: a república federativa. Poderíamos até mesmo ousar dizer que esta exposição da república federativa traz em si o molde através do qual foi cunhada a forma de governo a qual denominamos democracia moderna, em especial países como os E.U.A. e o Brasil. A república federativa de Montesquieu será a principal influência do Federalista.

Montesquieu começa argumentando que, como as grandes repúblicas, tanto faz se democracias ou aristocracias, estão sujeitas a vícios internos e pequenas invasões estrangeiras, um modo de garantir a segurança das mesmas é a república federativa, que faria a união das "vantagens internas do governo republicano" à "força externa da monarquia" (MONTESQUIEU, 1979, p. 127; IX, I) e formaria um Estado maior a partir do consentimento de vários corpos políticos em tornarem-se seus cidadãos, uma "sociedade de sociedades" (MONTESQUIEU, 1979, p. 127; IX, I).

Tendo visto a questão da república federativa, neste ponto, iremos discorrer sobre a teoria da separação dos poderes em Montesquieu. A teoria da separação já aparece em Locke (2001), onde os três poderes ficam separados, mas ainda em uma relação de subordinação entre eles. É Montesquieu (1979) que elabora esta teoria como a conhecemos hoje, com os poderes separados e no mesmo nível. É a teoria da separação dos poderes, com um sistema de freios e contrapesos, que vai caracterizar o que chamamos democracia moderna e que vai transformar qualquer teoria das formas de governo em algo inútil, pois passa-se a se tratar de uma mesma forma de governo, não importa se chamemos de democracia, como de fato o fazemos, monarquia, como o faz a Inglaterra, que também se considera uma democracia, e todos os outros países que adotam esta teoria em sua constituição.

Segundo Montesquieu, a teoria em questão introduz a moderação nos Estados, evitando o abuso de poder. "Para que não se possa abusar do poder é preciso que, pela disposição das coisas, o poder freie o poder” (MONTESQUIEU, 1979, p. 148; XI, IV). Para que isso aconteça, a constituição precisa ser estabelecida de forma que só se seja obrigado a fazer algo se a lei assim o estabelecer (XI, IV). É a teoria de Montesquieu que nos traz a divisão que temos hoje em legislativo, executivo e judiciário (no livro "poder de julgar”). Ele coloca o judiciário separado do legislativo e do executivo, com o judiciário exercido por pessoas do povo, o legislativo (a vontade geral do Estado) e o executivo (a execução desta vontade) outorgados de preferência a magistrados ou corpos permanentes.

Para Montesquieu, o povo deve possuir o legislativo, porém, isso é impossível nos grandes Estados, além de nos pequenos trazer muitos inconvenientes, o que nos leva à defesa dos representantes. Estes servem para fazer aquilo que o povo "não pode fazer por si mesmo" (MONTESQUIEU, 1979, p. 150; XI, VI). Como, para o autor do Espirito das Leis, o povo não possui a capacidade de discutir os negócios públicos, questão que vimos anteriormente, mas os representantes sim, sendo esta sua grande vantagem. Além disso, há em Montesquieu uma grande distância entre os representantes e o povo (importante lembrar em Locke da proximidade dos mesmos). Os representantes não precisam ser escolhidos geralmente do corpo da nação, cada localidade principal deve eleger um representante do seu próprio corpo, não precisam receber instruções particulares sobre cada questão, apenas instruções gerais, pois instruções particulares, apesar de permitir uma melhor expressão da vontade do povo, torna lenta a atuação dos representantes. Além disso, os 
representantes devem prestar contas aos eleitores e todos os cidadãos devem participar das eleições, exceto, e aqui Montesquieu faz uma ressalva à qual devemos prestar muita atenção, aqueles "em tal estado de baixeza, que são considerados sem vontade própria” (MONTESQUIEU, 1979, p. 150; XI, VI). Para Montesquieu, o povo não tem a capacidade de tomar resoluções ativas, e quando isso acontece é um vício do governo. Para ele, o povo deve limitar-se a escolher os representantes. Somando-se a isso, ele acreditava que as pessoas dignificadas por nascimento (por riquezas ou honrarias) deveriam participar na constituição de maneira proporcional às outras vantagens que já possuíam no Estado, formando assim um corpo com o direito de sustar as iniciativas do povo (e vice-versa, o povo também poderia sustar as ações desse corpo). Ou seja, o legislativo seria dividido em dois, com uma "bancada dos nobres" (denominação nossa, e não originalmente de Montesquieu), hereditária, e uma "bancada do povo", que fariam deliberações em separado e poderiam sustar as iniciativas uma da outra. Esta "bancada dos nobres" também teria o direito de atuar como um moderador do executivo e do próprio legislativo. Além disso, o poder executivo deveria pertencer a um monarca, a um só, que daria mais agilidade a este poder.

Para Montesquieu, o legislativo nem deve estar o tempo inteiro reunido, para não resultar em anarquia ou em poder absoluto do executivo, nem deve passar muito tempo sem se reunir, para não ocupar por demais o executivo, também não deve convocar a si mesmo, sendo a sua convocação é regulada pelo executivo, que determinaria o momento e a duração das assembleias e poderia vetar os seus empreendimentos. O legislativo não sustaria o executivo, mas examinaria a execução das leis, além disso, não julgaria a conduta do monarca, o que daria margem ao executivo tornar-se tirânico, mas poderia perseguir e punir os conselheiros do monarca.

O sistema de freios e contrapesos é uma estrutura onde há um campo de atuação de cada poder, a proibição de uns influírem nos campos dos outros, mas com o direito de sustar, vetar, examinar, as ações dos outros. Tal sistema formaria "uma pausa ou uma inação. Mas como, pelo movimento necessário das coisas, eles são obrigados a caminhar, serão forçados a caminhar de acordo” (MONTESQUIEU, 1979, p. 153; XI, VI).

Uma terceira lei fundamental da democracia que Montesquieu aponta seria a que afirma que só o povo deve instituir leis. Porém, ele faz a ressalva de que há “mil ocasiões” (MONTESQUIEU, 1979, p. 33; II, II) nas quais o senado deve instituir as leis, sendo estas decretos temporários que se tornariam leis perpétuas através da vontade do povo (II, II).

Por fim, em Montesquieu a questão é que, seja qual for a nomenclatura dada, monarquia, oligarquia ou democracia, trata-se, no fim das contas, de uma forma de governo mista, dividida em três poderes, com uma parte reservada no legislativo para a nobreza, sendo a sucessão aqui hereditária, e uma parte reservada para o povo, mas sendo este representado por "certos personagens" e um executivo ocupado por um monarca. Ironicamente, esta é a forma de governo, com tantos distanciamentos do povo, que hoje chamamos "governo do povo", "democracia".

\section{ROUSSEAU: O INIMIGO DA REPRESENTAÇÃO}

No Contrato Social (1973; II, II), Rousseau afirma que “a vontade ou é geral, ou não o é; ou é do corpo do povo, ou somente de uma parte. No primeiro caso, essa vontade declarada é um ato de soberania e faz lei; no segundo, não passa de uma vontade particular ou de um ato de magistratura, quando muito, de um decreto" (ROUSSEAU, 1973, p. 44). É, portanto, baseado em sua noção de vontade geral que o citoyen de Genéve opõe-se à existência das brigues, das facções no interior de um Estado. Se a vontade de uma facção se 
impõe a todo o corpo político, há uma ruptura deste e a facção passa a dominar o povo. Em vez da vontade geral, impera a vontade de todos.

Este último conceito é crucial para o entendimento da própria vontade geral, pois o genebrino conceitua esta em grande medida em oposição à primeira. A vontade geral prende-se ao interesse comum, enquanto a vontade de todos não passa de uma soma de vontades particulares. A vontade geral consiste no resultado da soma de todas as vontades particulares, despojada dos a-mais e dos a-menos que se chocam e se destroem, de forma que esta não precisa ser unânime, mas deve haver a contagem de todos os votos. Rousseau chega a afirmar que, se somados três fatores, povo informado, ausência de comunicação entre os cidadãos e deliberação, teríamos sempre a vontade geral. Já a vontade de todos reside nas facções, que, pela comunicação entre os cidadãos, força um acordo de vontades que faz prevalecer os interesses de um grupo em detrimento dos do povo. A vontade de todos é uma vontade geral apenas entre seus membros, mas particular em relação a todo o resto. Segundo o citoyen de Genève, quando uma facção atinge um tamanho capaz de se sobrepor a todas as outras, a vontade geral se cala (II, III). Baseado nessas reflexões, Rousseau enfatiza: "Importa, pois, para alcançar o verdadeiro enunciado da vontade geral, que não haja no Estado sociedade parcial e que cada cidadão só opine consigo mesmo" (ROUSSEAU, 1973, p. 27; II, III).

É bastante comum entre os estudiosos do filósofo genebrino a interpretação de que o cidadão, no momento de dar o seu voto, deveria abster-se de sua vontade particular e votar de acordo com o que ele acredita ser a vontade geral. Nossa interpretação, pelo contrário, é a de que a vontade geral só acontece se cada cidadão só opinar "de acordo consigo mesmo", como nos diz o próprio Rousseau, ou seja, de acordo com a sua própria vontade particular. É este o ponto no qual as facções tornam-se perigosas: elas são capazes de calar a vontade particular dos cidadãos e impor a delas, fazendo com que o cidadão deixe de ser livre no principal momento em que deveria expressar a sua liberdade.

Outra parte em que se baseia essa interpretação, a nosso humilde ver, errônea, é quando Rousseau afirma que "a vontade geral, para ser verdadeiramente geral, deve sê-lo tanto no objeto quanto na essência" (ROUSSEAU, 1973, p. 49; II, IV). Contudo, o sentido dessa frase já é dado logo em seguida: "essa vontade deve partir de todos e aplicar-se a todos" (ROUSSEAU, 1973, p. 49; II, IV), ou seja, a lei é para todos, a lei é geral, todos a fazem e ela a todos se dirige.

Como dito na frase citada três parágrafos acima, o citoyen de Genève acreditava ser possível um Estado sem facções, dando inclusive o exemplo de Esparta, contudo, reconhecia a dificuldade disso. Se não fosse possível extinguir as mesmas, seria preciso multiplicá-las, de forma que permaneçam pequenas o suficiente para não conseguirem superar a força do povo.

A esta questão da vontade geral e das facções, liga-se a crítica de Rousseau à representação no legislativo. Para ele, a existência de representantes tanto desliga o cidadão de sua atividade principal, que é o serviço público, tornando-o mais ligado ao dinheiro, ao lucro, quanto compromete a sua liberdade. A representação, ao contrário do que designa a própria palavra, permite, na prática, que uma facção domine o povo, fazendo o genebrino afirmar que "É nula toda lei que o povo diretamente não ratificar" (ROUSSEAU, 1973, p. 108; III, XV). Essa necessidade de ratificação, além de outros fatores como a alimentação e a defesa, também influencia no tamanho do Estado. Existe uma proporção direta entre o tamanho do Estado e o liame social, de modo que o Estado legítimo do Contrato Social é pequeno.

Facções, representação e tamanho do Estado são temas nos quais o Federalista (HAMILTON et al., 1973) vai se deter, em especial em seu capítulo X, para defender a forma de governo adotada pela Constituição dos E.U.A., que se tornou um cânone do que chamamos democracia moderna e que, de maneira especial, influenciou a forma do que hoje conhecemos por República Federativa do Brasil. 


\section{O OBJETIVO DO FEDERALISTA NELE MESMO}

O objetivo do Federalista (HAMILTON et al., 1973) foi fazer uma defesa da república federativa da Constituição Norte-Americana, ao invés de três ou quatro confederações parciais, como havia uma proposta na época. Era uma escolha de um governo central, único, em vez de soberanias isoladas, que criaria uma nação, "da sorte de um império" (p. 93), formada pela União dos treze Estados.

De acordo com Maggs (2007), a Convenção Constitucional em questão aprovou o texto em questão em setembro de 1787, contudo, havia ainda a necessidade de que a Constituição fosse ratificada por nove estados. Foi para esse objetivo que Alexander Hamilton, James Madison e John Jay escreveram a série de texto que compôs o Federalista, endereçando os referidos ao estado de Nova York. Segundo ele, o livro em questão é visto como uma fonte muito importante, a fonte secundária mais citada por acadêmicos e juristas, para o que seria o significado original da Constituição. O Federalista foi escrito entre os anos de 1787 e 1788 e foi também reproduzido em outros estados na época.

No Capítulo I, é colocada a questão da seguinte forma: "Se os homens são capazes de dar a si mesmos um bom governo por própria reflexão e escolha, ou se a Providência os condenou a receberem eternamente a sua constituição política, da força ou do acaso” (HAMILTON et al., 1973, p. 93). Há, portanto, a defesa de uma forma de governo considerada boa, a melhor para a América. O referido bom governo deveria ser "enérgico", entendendo, um tanto paradoxalmente, os autores que, sem vigor do governo, existiria uma impossibilidade para a liberdade.

Mais especificamente, os objetivos de discussão apontados na própria obra são: uma defesa da União e a insuficiência da Confederação que vigia na época; a necessidade de um governo enérgico; a conformidade da referida Constituição com os princípios republicanos e a analogia desta com os Estados particulares; e o aumento da segurança, da liberdade e da propriedade que a Constituição traria.

Em uma carta tardia, Madison descreveu o propósito do Federalista como: "O objeto imediato deles [dos textos] foi reivindicar e recomendar a nova Constituição para o Estado [de Nova York] cuja ratificação do instrumento, era duvidosa, assim como importante" (HAMILTON apud MAGGS, 2007; tradução nossa).

\section{A NATUREZA HUMANA E AS FACÇÕES}

O assunto das facções domina o Capítulo X e é a própria base filosófica da forma de governo defendida. Logo de início, os autores afirmam que a principal vantagem da federação é "amortizar e reprimir a violência das facções" (HAMILTON et al., 1973, p. 100). A facção, por sua vez, é definida como "uma reunião de cidadãos, quer formem a maioria ou a minoria do todo, uma vez que sejam unidos e dirigidos pelo impulso de uma paixão ou interesse contrário aos direitos dos outros cidadãos, ou ao interesse constante e geral da sociedade" (HAMILTON et al., 1973, p. 101). Neste ponto é muito importante salientar a presença da maioria na definição de facção, o que é bastante contraintuitivo, mas que já aparece em Rousseau (1973) e vai ter uma função determinante na defesa desta forma de governo.

No Federalista (HAMILTON et al., 1973), a facção é uma derivação da própria natureza humana, não havendo, portanto, como existir por livre e espontânea vontade dos homens uma sociedade sem facções. Estas seriam uma derivação natural das diversidades inerentes ao homem. Vejamos o que seriam essas diversidades naturais: Primeiro, a diversidade de opiniões, que surge do próprio uso da razão humana. Todavia, estas opiniões não estão ligadas apenas à razão, elas se relacionam também com as paixões do homem, fruto 
do seu amor-próprio. Segundo, a diversidade de faculdades humanas, da qual resulta a aquisição e que dá origem aos direitos de propriedade. Como há esta diversidade natural de faculdades humanas, há naturalmente a desigualdade de propriedade. Terceiro, a própria diversidade das propriedades dá origem à divisão da sociedade em proprietários e não-proprietários, credores e devedores, comerciantes, capitalistas etc., ou seja, diferentes classes, interesses e partidos - as facções.

Diversidade de opiniões, de paixões, de faculdades, de propriedade e de facções, esta seria a constituição natural da sociedade com a qual a constituição política defrontar-se-ia. Portanto, o fim principal da legislação, para os federalistas ${ }^{7}$, deve ser o de colocar regras que lidem com os interesses opostos existentes, devendo o espírito de partido e de facção entrar sempre no cálculo das operações do governo. Em suma, o governo deve evitar as facções.

\section{COMO EVITAR AS FACÇÕES: UM EMBATE ENTRE A REPÚBLICA E A DEMOCRACIA}

De acordo com os federalistas, há dois métodos de evitar as facções: ou previne-se as causas ou corrige-se os efeitos. Como as causas das facções estão fundadas na própria natureza humana, os métodos de prevenção, que são dois, são impraticáveis. O primeiro seria destruir a liberdade, ou seja, o despotismo, que é pior do que a existência das próprias facções e aniquila a própria vida política. O segundo seria dar aos cidadãos uma uniformidade de opiniões, paixões e interesses, o que não seria possível, já que a diversidade, como vimos, vem da própria natureza humana. Logo, como não podemos evitar as causas, devemos corrigir os efeitos.

Este ponto dá início a uma disputa entre a forma de governo proposta, uma república federativa baseada na representação, e a democracia (tida aqui como o governo popular, uma democracia direta). É esta disputa que nos dará boa parte das informações que procuramos, pois, através da argumentação contra a democracia, os federalistas vão nos dando as suas razões para manter o povo distante do poder.

Bentes (2006) faz um comparativo de definições bem direto ao ponto, salientando que "democracia" é definida como democracia direta, onde o povo governa pessoalmente, e a república como república representativa.

Para os federalistas (HAMILTON et al., 1973), os governos populares teriam a tendência de formar facções, levando a instabilidade, injustiça e confusão nos conselhos públicos. A presença de facções, de conflitos de partidos rivais, por sua vez, conduz ao esquecimento do bem comum, já que, na democracia, as questões são decididas pela força de uma maioria interessada e opressiva, passando por cima das regras da justiça e dos direitos do partido mais fraco. Quando a facção que visa desviar do bem comum não é a maioria, o remédio está no próprio princípio republicano, contudo, quando a maioria forma uma facção, o governo popular lhe dá todos os meios de sacrificar o bem público. Para os federalistas, "uma pura democracia, composta de um pequeno número de cidadãos, que se reúnem todos e governam por si mesmos, não admite remédio contra as desgraças da facção" (HAMILTON et al., 1973, p. 103). Nada pode reprimir o desejo de sacrificar o partido mais fraco. Logo, a democracia é incompatível com a segurança pessoal e

\footnotetext{
7 Hamilton, Madison e Jay assinaram todos os textos do Federalista com o pseudônimo "Publius". Concordamos com a posição de Peacock (2010) de que a utilização de um único pseudônimo mostra, em relação aos textos, uma uniformidade de intenção, um direcionamento para que o livro seja lido como se escrito por uma única pessoa. Peacock, assim como outros que seguem esta vertente, refere-se aos autores por "Publius". Nós, por acreditarmos ser mais simples para o público brasileiro, referimo-nos aos mesmos por "os federalistas".
} 
conservação dos direitos de propriedade.

Para eles, uma república, na forma de um governo representativo e federativo, oferece o remédio adequado para as facções, mas deixando a salvo o espírito e a forma do governo popular. Os meios para isso: não permitir que tal facção coloque em prática planos de opressão. Nesse ponto, somos da opinião de que a virtude assume a centralidade da condução do governo ao bem comum, da seguinte forma: sendo a república mais vasta, com mais cidadão, os poderes são delegados a um pequeno número de indivíduos escolhidos pelo povo. O efeito disso, segundo os federalistas, seria "depurar" e "aumentar" o espírito público, "fazendo-o passar para um corpo escolhido de cidadãos, cuja prudência saberá distinguir o verdadeiro interesse da pátria e que, pelo seu patriotismo e amor da justiça, estarão mais longe de o sacrificar a considerações momentâneas ou parciais" (HAMILTON et al., 1973, p. 104). "Num tal governo é mais possível que a vontade pública, expressa pelos representantes do povo, esteja em harmonia com o interesse público do que no caso de ser ela expressa pelo povo mesmo, reunido para este fim” (HAMILTON et al., 1973, p. 104). Ou seja, estes representantes, os virtuosos escolhidos pelo povo, saberiam melhor expressar a vontade do povo do que o próprio povo. Deste modo, observamos que os federalistas trazem de volta a virtude à centralidade do núcleo argumentativo da filosofia política.

Bentes (2006) aponta que os federalistas tencionavam transformar a cidadania privada em ação cívica ocasional, criando, ao mesmo tempo, uma classe de políticos profissionais, de forma que o conceito de soberania popular torna-se puramente formal, o que leva Miller (1988) a chamar a retórica do Federalista de “pseudodemocrática”. Neste ponto, Bentes (2006) faz a ligação com Montesquieu, na seguinte passagem: "A grande vantagem dos representantes é que são capazes de discutir os negócios públicos. O povo não o é de modo algum, capaz disso, fato que constitui um dos graves inconvenientes da democracia” (MONTESQUIEU apud BENTES, 2006, p. 41).

Mas e se os representantes escolhidos não fossem esses virtuosos e sim representantes de interesses facciosos? Nesse caso, segundo os federalistas (HAMILTON et al., 1973), o tamanho da república, uma grande república, já traria a melhor solução. Como o número de representante nas repúblicas maiores é proporcionalmente menor em relação ao tamanho do povo e sendo os talentos e as virtudes igualmente distribuídos tanto nas repúblicas maiores quanto nas menores, haverá mais pessoas elegíveis nas grandes repúblicas e, logo, probabilidade maior de fazer uma boa escolha. Além disso, como nas grandes repúblicas os representantes são eleitos por um maior número de pessoas, não seria tão fácil que candidatos sem merecimento se elegessem.

Contudo, para os federalistas, a proporção entre eleitores e representantes deve ter um equilíbrio. Se aumenta-se muito o número de eleitores, os representantes perdem contato com as localidades, se diminuise muito, estes ficam em dependência muito imediata dos eleitores, que não reconhecerão o interesse geral da nação e não se conformarão com este na eleição que fizerem. Para os federalistas, esta combinação é melhor cumprida pelo governo federativo, com os interesses gerais confiados à legislatura nacional e os particulares e locais aos legisladores estaduais.

Um ponto a ser ressaltado é a afirmação de que os eleitores não reconheceriam o interesse geral da nação e a proximidade dos representantes seria algo capaz de afastar o governo desse interesse geral. Em outras palavras, os federalistas entendem que precisa haver uma certa distância entre o poder e o povo, que, mesmo havendo a necessidade de manter contato com as localidades, é benéfico que os representantes não sofram uma pressão direta de quem os elegeu.

Além disso, o tamanho das repúblicas federativas, com um maior número de cidadãos e um território mais vasto do que as democracias, termina por tornar os planos dos facciosos menos temíveis. Menor a 
sociedade, menos partidos, menos diferença de interesses, torna-se mais fácil o mesmo partido reunir maioria. Quanto menor o número de indivíduos para compor maioria, mais facilmente ela coloca em prática planos de opressão, e vice-versa. E em relação à União, que era uma das principais ideias que os federalistas defendiam, a vantagem seria ainda maior, pois os chefes facciosos poderiam influir nos seus Estados, mas não no corpo inteiro da União. Com isso, os federalistas concluem que a União já traz consigo um remédio contra os males a que o governo republicano está normalmente sujeito.

\section{A QUESTÃO DA INFLUÊNCIA EXTERNA}

Ao defender a União, os federalistas tinham em mente a situação externa com a Inglaterra e com os povos marítimos. No capítulo XI, eles afirmam que a existência da União, pela força comercial que desta decorreria, torná-los-ia os árbitros da Europa, e, na situação contrária, esta não existindo, a rivalidade entre os Estados independentes geraria um estado de fraqueza, de impotência, diante das empresas de outras nações, perdendo, inclusive, o direito à neutralidade e tendo sua existência política prescrita por outros.

A análise geopolítica que eles faziam era a de que o mundo fora dividido em quatro partes, Europa, América, África e Ásia, tendo a Europa subjugado as outras três, tanto pelas armas quanto pelas negociações. Isso gerou um sentimento de superioridade nos Europeus, no qual eles se achavam senhores do universo, superiores fisicamente. Aos americanos caberia "restabelecer a honra da raça humana ofendida e ensinar o que é moderação a irmãos usurpadores” (HAMILTON et al., 1973, p. 111), e isso seria viabilizado pela existência da União.

\section{SOBRE A CONFEDERAÇÃO ATUAL}

O capítulo XV trata da confederação que existia na época. Segundo os federalistas, esta seria insuficiente para que a União fosse mantida. Faltaria energia ao governo. Os males dos quais os E.U.A. estariam sofrendo na época decorreriam de erros fundamentais na estrutura da Confederação, erros que só poderiam ser corrigidos alterando-se a base e os alicerces da Constituição. O que foi chamado o vício radical da Confederação estaria no fato de que a autoridade legislativa da União apenas exercitar-se-ia sobre corpos e não sobre os indivíduos que formam esses corpos. Este vício teria influência em poderes cruciais, dos quais dependeria a eficácia de todos os outros, tendo como consequência prática o fato de as leis obrigatórias a todos os membros da União, na verdade, não passarem de meras recomendações, que os Estados podem cumprir ou não, a depender dos seus interesses. Resolvendo este vício, haveria a troca da resolução pelas armas pela autoridade dos magistrados, ou seja, a União serviria para decidir sobre os conflitos entre os Estados.

Para os federalistas, uma liga de nações independentes, que estabelecem um contrato com objeto, tempo, lugar, circunstâncias e quantidades definidos é algo viável, mas há uma grande insegurança envolvida nesse tipo de acordo, como foi o caso da Europa, onde os países fizeram abundar alianças, que se desfaziam rapidamente, por ciúmes e rivalidades, e deixavam a lição de que não se deveria confiar em tratados. Se, contudo, afirmam eles, os E.U.A. se decidiram por um governo geral, devem aceitar os princípios fundamentais que diferem um governo de uma liga: a autoridade da União deve chegar até os cidadãos. A execução das leis deve ser afiançada pela sanção. Sem pena, as leis não passam de recomendações. Quem garante a pena ou é um tribunal, que funciona com indivíduos, ou o poder militar, que é o único que funciona com Estados. Cada violação de um Estado das leis traz consigo um estado de guerra. A consequência lógica disso 
é que um Estado provavelmente não ousaria levantar suas armas contra os outros doze.

\section{POR QUE SE ESTABELECE UM GOVERNO?}

Os governos existem porque as paixões dos homens não obedecem espontaneamente à razão e à justiça. As massas obram com ainda menos desinteresse e retidão do que os indivíduos. Em grupo, o temor de perder a reputação diminui, "o espírito de facção, cujo veneno infecta tantas vezes as deliberações de todos os corpos políticos, pode arrastar certas pessoas a erros e demasias de que cada uma delas se envergonharia se se achasse sozinha" (HAMILTON et al., 1973, p. 117). Também, o poder dá àqueles que nele se encontram uma "impaciência de contradição" (HAMILTON et al., 1973, p. 117), não gostando de ser restringido ou dirigido. Disso decorre que, nas associações políticas, as muitas associações particulares que a compõem são animadas por uma força contrária à associação maior. Em outras palavras, as facções que existem no interior de um Estado agem em sentido contrário ao mesmo. A origem disso está no amor ao poder. O poder restringido rivaliza com o que o restringe. As pessoas que administram os negócios públicos não estão dispostas a executar as resoluções da autoridade geral com a satisfação e o desinteresse necessários para o bem público, e isto faz parte da natureza humana.

Segundo os federalistas, na prática, sob a Confederação vigente na época, as resoluções da União não foram cumpridas pelos Estados, o que, ainda segundo eles, gerou uma imobilidade política no país.

\section{A FORMA DE GOVERNO PROPOSTA}

Para os federalistas, a maior dificuldade dos constituintes era "conciliar a estabilidade e a energia necessárias do governo com o respeito devido à liberdade e às formas republicanas" (HAMILTON et al., 1973, p. 120). A energia seria para defender o país dos perigos internos e externos, fazer executar as leis e dar estabilidade, exigindo a prolongação do poder e o executivo nas mãos de apenas uma pessoa. A forma republicana, por sua vez, exige que o poder emane do povo e que os depositários do poder público dependam do povo pela curta duração dos cargos e pelo número elevado de depositários.

Segundo eles, no capítulo XXXIX, a forma de governo proposta na convenção é fundada sobre princípios republicanos, pois este seria a única forma de governo compatível com o caráter do povo americano. Para eles, "governo republicano é aquele em que todos os poderes procedem diretamente ou indiretamente do povo e cujos administradores não gozam senão de poder temporário, a arbítrio do povo ou enquanto se portarem" (HAMILTON et al., 1973, p. 124), sendo da sua essência que "a maioria da sociedade tenha parte em tal governo" (HAMILTON et al., 1973, p. 125). Contudo, aqui eles fazem o distanciamento do governo em relação ao povo: "É bastante, para que tal governo exista, que os administradores do poder sejam designados direta ou indiretamente pelo povo” (HAMILTON et al., 1973, p. 125).

Neste governo, das principais instituições, apenas uma é eleita imediatamente pelo povo, que é a Câmara dos Representantes. Esta câmara seria eleita a cada dois anos e, como o Legislativo é bicameral, é apenas uma metade do mesmo. Já o Senado seria eleito indiretamente, a cada seis anos. O presidente, chefe do Executivo, também chegaria ao poder por eleições indiretas. A proibição de títulos de nobreza seriam a garantia da forma de governo republicana.

Os federalistas terminarão por concluir que se trata de uma forma de governo mista, parte federativa, parte nacional. O método para se aferir qual seria o verdadeiro caráter do governo seria considerá-lo pelo princípio a partir do qual foi estabelecido, pela origem do poder e por quem poderia promover alterações 
na sua estrutura. Em relação ao princípio, o governo repousa no assentimento e ratificação do povo, este não simplesmente considerado como uma nação, mas como cidadãos de diferentes Estados, em outras palavras, o governo assenta-se em um ato federativo, em uma decisão unânime de todos os Estados, e não na da vontade da maioria do povo da União. Cada Estado, na qualidade de corpo soberano, ligou-se à União por um contrato voluntário. Dizendo respeito à origem do poder, a Câmara dos Representantes deriva do povo e possui uma representação proporcional a este, o que dá um caráter nacional à Constituição, e o Senado uma representação igualitária, com o mesmo número de representantes para cada Estado, o que dá um caráter federativo. No Poder Executivo, a origem é mista, com a eleição primária composta e a imediata levada a cabo pelos Estados. Em relação à autoridade capaz de realizar reformas no sistema, também temos um caráter misto. Se fosse nacional, esta autoridade seria a maioria do povo da União, tendo o tempo todo o direito de abolir ou mudar o governo, se federativa, todos os Estados teriam que concorrer para fazer uma alteração. O modelo adotado exige mais do que a maioria, em um cálculo proporcional ao número dos Estados, e, em outros casos, não exige o concurso de todos os Estados.

Sobre a separação dos poderes, os federalistas citam diretamente Montesquieu. No capítulo XLVII, diante de uma crítica de que a nova Constituição não respeitaria apropriadamente a separação dos três poderes, eles propõem examinar aquilo que é essencial na separação. Para os autores norte-americanos, Montesquieu via a Constituição Inglesa como o cânone da liberdade política e, nesta, os três poderes não se encontravam totalmente separados, cada um deles realizava atos, ações parciais, dentro do âmbito dos outros poderes. A essência da separação dos poderes seria que dois poderes estivessem em sua plenitude nas mãos de uma única pessoa, como, por exemplo, um monarca possuir tanto o Legislativo quanto o Executivo, podendo elaborar leis tirânicas e fazê-las cumprir tiranicamente.

No capítulo LI, os federalistas continuam o assunto da separação dos poderes, expondo a razão de ser dessa teoria: fazer uso da oposição dos interesses, um interesse corrigindo o outro. Para isso, é necessário que cada poder tenha sua própria vontade, que as nomeações para as magistraturas supremas de cada um deles venham do povo, que funciona como o primeiro regulador do sistema. Outros reguladores entram em ação, por exemplo, como o Legislativo tenderia naturalmente a dominar o governo, deve ser dividido em frações que são eleitas e agem por diferentes princípios, e como o executivo tem a tendência a ser fraco, deve ser fortalecido por mecanismos como o veto absoluto.

Em seguida, os referidos norte-americanos fazem a diferenciação entre república simples e composta, afirmando ser a Constituição dos E.U.A. do segundo tipo. A república simples, segundo eles, seria aquela na qual toda a autoridade delegada pelo povo é exercida por um governo único, cabendo à separação dos poderes proteger o povo contra as usurpações do poder. Já na composta, que é a da Constituição defendida, dois governos distintos dividem essa autoridade, sendo essas duas porções ainda subdivididas em outras frações (os dois governos seriam a União e cada Estado e tanto a União quanto todos os Estados se subdividem em três poderes). Todas essas divisões, segundo os federalistas, garantiriam uma segurança ainda maior para os direitos do povo.

Uma outra vantagem do sistema federativo proposto, segundo os federalistas, é que este, além de poder defender o povo contra a tirania dos governantes, é capaz de defender a minoria contra a injustiça da maioria. A argumentação desenvolve-se no seguinte sentido: como as diferentes classes de uma sociedade têm interesses diversos, os direitos da minoria ficam em perigo quando a maioria se une em torno de um interesse comum e, para prevenir isto, há duas vias, ou cria-se no interior da sociedade uma vontade independente da maioria, que é o que acontece em governos hereditários ou estabelecidos pela força e que pode não surtir o efeito desejado, já que o poder independente em questão pode muito bem favorecer a injustiça 
da maioria, ou procede-se como na Constituição defendida, com a autoridade provindo da sociedade e dependendo desta e sendo a própria sociedade dividida em muitos partidos, em interesses muito diversos e em muitas classes de cidadãos, o que garante que dificilmente a maioria ataque os interesses da minoria ou mesmo de indivíduos isolados.

Segundo os autores, o fim do governo é a justiça. Estaria em anarquia tanto o governo onde uma facção pode reunir-se contra um partido com menor poder quanto aquele onde um indivíduo não é defendido contra uma horda de bárbaros. Eles então afirmam que se, por exemplo, o Estado de Rhode Island se separasse e estabelecesse um governo popular, certamente uma maioria facciosa injusta colocaria em incerteza os direitos individuais, tendo, em consequência, esta própria maioria a necessidade de "invocar o auxílio de um poder inteiramente independente do povo" (HAMILTON et al., 1973, p. 139). Por outro lado, em uma república da extensão dos E.U.A., devido ao elevado número de interesses, partidos e seitas, dificilmente a maioria unir-se-ia por motivos outros que não os da justiça ou do interesse geral, não havendo mesmo pretexto plausível para defendê-la, como nos mostra o seguinte trecho:

numa república tão extensa como a do Estados Unidos, com tão grande número de interesses, de partidos e de seitas diferentes, dificultosamente se coalizará a maioria por outros motivos que não sejam os da justiça e do interesse geral; e como em tal estado de coisas a minoria tem menos motivos de recear, tanto mais dificultoso será encontrar pretexto plausível de defendê-la, a fim de introduzir no governo uma vontade independente da maioria, isto é, da mesma sociedade (HAMILTON et al., 1973, p. 139).

Logo, para os federalistas, quanto maior a sociedade, mais facilmente ela governa a si mesma (não ultrapassando os limites da prudência).

\section{AS PARTES DO GOVERNO}

Sobre a câmara dos representantes, capítulo LII, as condições para se eleger são as mesmas que para ser eleitor. Os que podem se eleger devem ter mais de vinte e cinco anos, ter sete anos de cidadania e ser habitante do Estado que deve representar. Assim, segundo os federalistas, as posições ficam abertas ao mérito dos cidadãos "naturais ou adotivos, $[\ldots]$ ricos ou $[\ldots]$ pobres, $[\ldots]$ velhos ou $[\ldots]$ moços, $[\ldots]$ protestantes ou [...] católicos” (HAMILTON et al., 1973, p. 140). As eleições são bienais, e sobre isso os autores afirmam:

sem que o governo em geral tenha com o povo comunidade de interesses, não pode haver liberdade. Ainda mais: é essencial que a parte do governo que estamos examinando esteja em imediata dependência do povo e que esteja com ele em simpatia perfeita. Ora, a frequência das eleições é o único meio de segurar esta simpatia e aquela dependência: qual seja, porém, o grau de frequência absolutamente necessário para este efeito é o que não pode determinar-se com precisão (HAMILTON et al., 1973, p. 141).

O número de membros é proporcional à população de cada Estado. Uma observação a ser feita é em relação aos escravos na época. Segundo os federalistas, estes eram vistos pela Constituição como um misto de pessoa e propriedade, sendo, de certa forma, levados em consideração como população do Estado, pois esta era contada juntando-se três quintos dos escravos ao número de pessoas livres.

Em relação ao Senado, capítulo LXII, podem ser escolhidos cidadãos com o mínimo de trinta anos de idade e nove de cidadania. Os senadores são nomeados pelas legislaturas particulares, o que, segundo os autores, teria a vantagem de "favorecer uma escolha mais ilustrada" (HAMILTON et al., 1973, p. 149) e 
“dá, ao mesmo tempo, aos Estados uma influência sobre a formação do governo federal, que procurará segurança de autoridade aos seus governos e formará entre os dois sistemas um laço útil” (HAMILTON et al., 1973, p. 148).

Toda a ideia dos federalistas em relação ao Senado é que este seja uma espécie de moderador, de freio, das ações da Câmara dos Representantes. Sobre a necessidade deste corpo, os autores citam quatro razões: (1) Como os que exercitam as funções do governo podem trair os seus deveres, o Senado seria um obstáculo à prevaricação, já que é parte distinta na Assembleia Legislativa e participa da outra parte. Com a sua existência, os planos de usurpação tornar-se-iam mais difíceis de serem executados, pois haveria a necessidade de se corromper dois corpos diferentes; (2) Há nas assembleias únicas e numerosas as tendências de ceder às paixões súbitas e violentas e de ser arrastada, por chefes facciosos, para ações precipitadas e imprudentes. O Senado, portanto, não tendo os defeitos da Câmara dos representantes, é capaz de corrigir os defeitos desta última; (3) O Senado corrige a falta de conhecimento em legislação que pode haver na Câmara, que se compõe de um grande número de pessoas com mandatos curtos. Os senadores teriam mais tempo e necessidade do estudo das leis, negócios e interesses do país; (4) A Assembleia Legislativa, sendo ela frequentemente renovada, conduz a uma inconstância que exige a presença de um elemento menos instável.

Os federalistas definem um bom governo como aquele que "supõe duas coisas essenciais: constância de atenção à felicidade do povo, que é o único objetivo do governo, e conhecimento dos meios que conduzem com mais certeza a este fim" (HAMILTON et al., 1973, p. 150). Desta forma, podemos observar que o Senado é o elemento-chave a preservar a virtude no governo. É tanto o elemento que produz a constância quanto aquele mais estudado, que conhece os meios de levar o governo ao seu fim. (que antes era chamado bem comum, aqui "felicidade do povo", substituição esta que parece uma mera utilização de sinônimos, mas que é cheia de significados ocultos).

Entre as consequências indesejáveis da inconstância dos governos, o que vem a ser remediado pelo Senado, os federalistas citam (1) a destruição da estima e da confiança das outras nações, (2) o prejuízo da liberdade, pois, mesmo tendo leis feitas por representantes eleitos, o povo se depara com leis volumosas demais para serem lidas ou incoerentes ao ponto de não poderem ser entendidas e que, para piorar, ainda passam por constantes mudanças, o que termina por resultar no desconhecimento do povo a respeito de suas próprias leis, (3) o fato de que os indivíduos "sagazes, empreendedores e dinheirudos" (HAMILTON et al., 1973, p. 151) teriam uma grande vantagem sobre o povo, pois novos regulamentos sobre comércio e finanças são, para o primeiro grupo, possibilidades de especulação sobre as variações nesses âmbitos, grandes oportunidades de negócios, já que estes conhecem bem essa área e podem prever os resultados, o que é feito às custas do trabalho dos cidadãos, (4) a falta de confiança do corpo legislativo terminar por desanimar todas as empresas úteis, que, afinal, dependem da estabilidade das leis, (5) - esta consequência está no capítulo LXIII - a frequência das eleições pode destruir a responsabilidade do governo para com o povo. Para os federalistas, as medidas complexas e graduais, que surtem efeito apenas em muitos anos, contribuindo para a prosperidade constante e geral do país, não podem ser cobradas de representantes com mandato tão curto, pois não seria possível verificar a sua responsabilidade.

Os federalistas, então, reafirmam o papel do Senado como um corpo mais permanente em sua missão, capaz de uma constância de atenção e de ser responsabilizado por uma longa sucessão de medidas. A essa constância, mais uma vez, é atrelada a questão da virtude. Esta ligação, desta vez, é feita em um nível mais além, não dizendo só respeito aos defeitos da Câmara e só papel do Senado em defender o povo dos defeitos desta, mas ao papel do Senado em defender o povo dos "erros e ilusões momentâneas" 
(HAMILTON et al., 1973, p. 154) do próprio povo. Os autores afirmam que é uma regra geral "que a decisão refletida e espontânea da comunidade deve prevalecer em todos os governos livres às intenções daqueles que o governam" (HAMILTON et al., 1973, p. 154), contudo:

há [...] momentos particulares nos negócios públicos, em que o povo, estimulado por paixões irregulares, seduzido por vantagens ilegítimas ou enganado por argumentos capciosos de homens interessados, pode solicitar medidas que bem depressa desaprovará e cujos efeitos virá mais tarde a deplorar. Nestes momentos críticos, quanto deve ser salutar a interposição de um corpo de cidadãos respeitáveis e moderados, que reprima o impulso funesto da multidão e que suspenda o golpe que o povo está para descarregar em si mesmo, até que a razão, a justiça e a verdade retomem o seu império sobre o espírito público! (HAMILTON et al., 1973, p. 154).

Ora, esta passagem nada mais é do que a reintrodução do argumento da tirania do povo e o de que a virtude é o que deve conduzir o governo aos seus próprios fins. O Senado seria este repositório da virtude que, em última instância, teria o poder de proteger o povo de si mesmo. Segundo os federalistas, as repúblicas que não tiveram um Senado pereceram em pouco tempo, como Atenas.

Então os autores norte-americanos partem para o elogio ao princípio representativo: "A vantagem mais importante do governo americano sobre as outras repúblicas é ter por base o princípio representativo" (HAMILTON et al., 1973, p. 155). Segundo eles, "a ignorância das antigas repúblicas, a respeito do sistema representativo, não era tão grande como geralmente se pensa” (HAMILTON et al., 1973, p. 156). Essas repúblicas, como Atenas, Cartago, Esparta, Roma e Creta, tinham componentes representativos em suas constituições. A diferença entre estas repúblicas antigas, para os autores, e a americana é que "o povo, em corpo, jamais pode governar imediatamente entre nós; e é precisamente esta diferença que dá ao governo dos Estados Unidos tão grande superioridade sobre os outros” (HAMILTON et al., 1973, p. 156).

Em seguida, eles respondem à seguinte objeção: um Senado não eleito diretamente pelo povo, com cada membro em exercício por seis anos, começaria a adquirir preponderância no governo até se tornar uma aristocracia tirânica. A isso, os federalistas respondem que, ainda mais temíveis para a liberdade que os abusos de poder são os abusos da própria liberdade, coisa que os Estados Unidos estariam mais arriscados naquele momento. Segundo eles, para que houvesse tirania no novo sistema, seria preciso que, primeiro, o Senado se corrompesse, depois, este corpo corrupto teria que corromper as legislaturas dos estados, a Câmara dos Representante e, por fim, todo o povo. A lógica é a de que um corpo barra os efeitos da corrupção do outro, além da renovação dos dois corpos, que traz tudo de volta à estaca zero. Portanto, para que o Estado se torne corrupto, seria preciso que todo o povo se corrompesse.

A respeito do Poder Executivo, a principal crítica que os federalistas procuram desfazer é a de que a energia do poder em questão, na figura do Presidente, ou seja, o poder nas mãos de um só, seria incompatível com a índole da forma de governo republicana. Segundo eles, tal energia é uma das principais características de uma boa constituição, por trazer segurança contra os ataques estrangeiros à administração das leis, proteger a propriedade contra as investidas dos poderosos, assegurar a liberdade contra o "furor" (HAMILTON et al., 1973, p. 162) das facções e "projetos de ambição" (HAMILTON et al., 1973, p. 162). O poder Executivo precisa ter a força para executar as leis e governar. Segundo eles, "execução fraca é o mesmo que má execução” (HAMILTON et al., 1973, p. 162).

Para os federalistas, a energia deste poder está "na sua duração, na sua unidade, na suficiente extensão dos seus poderes, nos meios de prover as suas despesas e as suas necessidades" (HAMILTON et al., 1973, p. 162). Já a segurança de uma república está “na responsabilidade dos funcionários e na influência razoável 
das vontades do povo" (HAMILTON et al., 1973, p. 162). Assim afirmam: "a energia é filha da unidade" (HAMILTON et al., 1973, p. 162-163).

Quando se depende de muitas pessoas com a mesma autoridade para se realizar uma empresa, o risco de divergência de opiniões está sempre presente, e a autoridade termina sendo enfraquecida, as mais importantes medidas frustradas e a sociedade dividida em facções lideradas pelos próprios magistrados. Com a presença dessas facções inconciliáveis, os projetos passam a ser rejeitados com base na autoria dos mesmos, por não ser um projeto daquela facção ou por não se estimar as pessoas que o criaram.

De acordo com os federalistas, a república deve passar por tais transtornos no Legislativo, mas não no Executivo. No Legislativo, apesar das dificuldades, a divergência induz a uma maior reflexão e a uma "repressão dos excessos da maioria” (HAMILTON et al., 1973, p. 164). Mas, uma vez tomada a decisão no Legislativo, é preciso energia para colocá-la em prática. Dizem eles: "a resolução é a lei a qualquer resistência ulterior é um ato punível” (HAMILTON et al., 1973, p. 164). No Executivo, a dissensão não traz vantagens, pois é preciso prontidão. Até mesmo a existência de um conselho executivo que condicionaria e daria assentimento às decisões do presidente traria essa dissensão e lentidão ao Executivo. Além disso, segundo os autores, a pluralidade no Executivo tende a encobrir a culpa e anular a responsabilidade dos governantes, pois confunde a opinião pública, que não se fixa, e dificulta a identificação dos autores de medidas perniciosas. Para eles, a opinião pública e a punição, as penas legais, são os maiores fiadores da responsabilidade dos governantes.

Já a respeito do Judiciário, os federalistas dizem não ter havido questões levantadas, trazendo, portanto, os autores, apenas a descrição do que estava escrito no projeto de constituição para este poder. A organização do poder judiciário não é importante para os questionamentos feitos neste trabalho, portanto, limitar-nos-emos a um breve resumo. Em poucas palavras, trata-se de uma judicatura federal, cuja nomeação se dá como o restante dos empregados da União, desempenha suas funções tendo a garantia da inamovibilidade e é um freio aos outros poderes.

\section{CONCLUSÃO}

A partir da problematização estabelecida por Singer (2000), de que as democracias sofrem hoje um descrédito em relação aos seus processos, com o agravante na América Latina destas não terem ao menos se consolidado, e discordando do seu caminho de buscar um terreno comum entre o Federalista (HAMILTON et al., 1973) e Rousseau (1973), terreno este que acreditamos não existir devido à oposição clara em seus intentos, decidimos abordar o Federalista (HAMILTON et al., 1973) buscando saber qual é o quantum de poder que o povo possui sob a Constituição que é ali defendida. A análise foi realizada através da teoria das formas de governo, buscando observar os papéis dos conceitos de virtude e de vontade na forma de governo defendida, em que medida o povo influi nos rumos do governo e qual seria a relação da virtude com a possibilidade desta influência. Como pano de fundo de nossa análise, utilizamos Locke (2001), Montesquieu (1979) e Rousseau (1973), observando o tratamento que tais filósofos dão à ideia de representação.

Observamos que tanto Locke (2001) quanto Montesquieu (1979) defendem a ideia de representação. Locke (2001) identifica a vontade do povo como a determinação da maioria. Também prevê uma divisão em três poderes, na qual o legislativo pertenceria ao povo e estaria acima dos outros poderes. Contudo, o legislativo pertencente ao povo poderia ser composto, segundo Locke, por representantes eleitos pelo povo e que voltariam a ser cidadãos após terem elaborado as leis. Somos da opinião de que Locke, ao definir a sua melhor forma de governo, não assumiu as decorrências naturais da sua própria teoria, já que, como o 
legislativo pertence ao povo e a democracia direta, que ele chama de perfeita, seria a maior expressão disso, essa deveria ser apontada como a melhor, mas Locke aponta para uma democracia representativa, com o legislativo composto por assembleias de composição variável, com os legisladores voltando à condição de cidadãos assim que terminam de elaborar as leis. Podemos, então, observar que a representação em Locke ainda possui uma grande vinculação com o povo, já que as leis são compostas por cidadãos eleitos, mas que não formam uma classe de políticos profissionais.

A nosso ver, a falta de justificativa de Locke em inserir um sistema representativo já escondia uma intenção que fica clara posteriormente em Montesquieu (1979). Este foi o grande construtor teórico do sistema que hoje chamamos "democracia", e é na sua argumentação sobre a democracia que ele faz a sua defesa da representação, sob uma série de ressalvas. Diz que o povo nem tudo pode realizar, devendo, portanto, realizar apenas aquilo que o pode fazer corretamente e deixar o que não consegue para ministros ou magistrados; que o povo sabe a quem confiar parte da sua autoridade, mas não sabe "dirigir um negócio, conhecer os lugares, as ocasiões, os momentos e aproveitá-los" (MONTESQUIEU, 1979, p. 32; II, II). Além disso, na sua defesa de que os representantes devam ser eleitos por voto aberto, afirma que a "plebe" deve ser "esclarecida pelos principais e contida pela seriedade de certos personagens" (MONTESQUIEU, 1979, p. 33; II, II). A partir disso, interpretamos que, em Montesquieu, há a volta à noção da filosofia política antiga de que a virtude é o que deve conduzir o governo aos seus fins, colocando, em consequência, no poder um número reduzido de pessoas consideradas virtuosas.

Além disso, é de Montesquieu a teoria da separação dos poderes que temos ainda hoje, teoria que, junto com a da federação, cunhou a forma de governo à qual chamamos hoje "democracia". Com os poderes separados e no mesmo nível e com um sistema de freios e contrapesos, qualquer teoria das formas de governo torna-se algo inútil, pois, no fundo, só há uma forma de governo, um governo misto, que é uma mistura de elementos da monarquia, da aristocracia e da democracia, onde haveria uma representação do povo (esta, ainda assim, muito distante) e da nobreza no legislativo e o executivo seria formado por magistrados ou corpos permanentes, que, no fim das contas, Montesquieu afirma dever pertencer a um só (um monarca).

Este governo misto traz em si uma grande distância entre o povo e o poder. Os representantes agindo apenas por instruções gerais e o povo limitando-se a escolher os representantes. Além disso, vimos que ele prevê um legislativo bicameral, com uma das câmaras reservada àqueles dignificados pelo nascimento (a nobreza), com direito a sustar as iniciativas dos representantes do povo (e vice-versa) e agir como um moderador do executivo e do legislativo.

O filósofo político que vai na contramão desse sistema representativo, assumindo, a nosso ver, a tendência da modernidade em afirmar que o governo deve ser dirigido pela vontade do povo é Rousseau (1973). Conhecido como um grande crítico da representação, o cerne do seu Contrato Social é que o povo deveria determinar diretamente os rumos do governo através das leis, que seriam a expressão da vontade geral. Ou seja, o legislativo seria composto pelo próprio povo, que exerceria o seu poder diretamente. A grande preocupação de Rousseau em relação ao direcionamento do governo ao bem comum é a questão das facções (brigues). Estas teriam o potencial de desviar a vontade do povo, vontade geral, que aponta sempre para o bem comum, e fazer valer os seus interesses particulares, formando a vontade de todos, que é nada mais do que a vontade de uma facção. Para Rousseau, seria possível a existência de um Estado ou sem facções ou com tantas delas que nenhuma conseguiria impor sua vontade ao corpo político.

O Federalista (HAMILTON et al., 1973), por sua vez, faz uma espécie de contraposição a Rousseau, considerando ser impossível uma sociedade sem facções. A defesa aqui é de uma minoria contra a maioria. 
A defesa de um governo federativo vai se basear principalmente na precaução contra o poder das facções. A federação, que já aparece em Montesquieu, aqui aparece na figura da União, que se colocará acima dos estados.

O Federalista tem um objetivo muito diferente dos livros de Locke, Montesquieu e Rousseau, pois se propõe a defender a ratificação de uma Constituição específica, com uma forma de governo já estabelecida, que seria a melhor para os E.U.A.. O tema da federação deriva diretamente de Montesquieu e aqui é defendido como aquilo que possibilitaria a energia do governo. Um paradoxo é defendido: sem vigor por parte do governo, não haveria espaço para a liberdade.

Este paradoxo é todo ele explicado pelo tema das facções, um tema discutido tanto em Montesquieu quanto em Rousseau. É importante lembrar que em Locke não há exatamente um pensamento de proteção da minoria, o Estado deve ser dirigido pela vontade da maioria. Em Montesquieu há esta preocupação, mais especificamente uma preocupação com o lugar da nobreza, que ganha uma metade do legislativo. Em Rousseau, a facção termina por desviar o Estado do bem comum, transformando a vontade geral em vontade de todos, sendo algo a ser banido ou anulado da sociedade. Já no Federalista a facção ganha status de natureza humana, está na natureza do homem, sendo fruto da diversidade, logo, não existiria sociedade sem facções e a defesa da minoria ganha destaque. Uma das causas dessa diversidade é a desigualdade de propriedade, que é vista no Federalista como algo natural. O assunto das facções é a base filosófica da defesa da forma de governo em questão. A federação viria para lidar, amortizando ou reprimindo, a violência causada pelas facções. Para os federalistas, o fim principal da legislação é estabelecer leis que lidem com os interesses opostos naturalmente existentes. O fim do governo, em resumo, é evitar as facções.

Entendendo que a única forma de evitar as facções é corrigindo os seus efeitos, os federalistas consideram, por consequência, que a democracia não é uma forma de governo boa. É muito importante salientar que, primeiro, os federalistas não consideravam a forma de governo dos E.U.A. uma democracia, como o fazemos hoje (eles entendiam democracia como democracia direta), e, segundo, a democracia, ou seja, a participação do povo no poder era vista como sinônimo de instabilidade, injustiça e confusão, como a ação de uma maioria interessada e repressiva atropelando a minoria, sacrificando o partido mais fraco. Se a maioria desvia do bem comum, não haveria nada para a deter. Então eles concluem que a democracia é incompatível com a segurança pessoal e os direitos de propriedade. Depreende-se do texto que bem comum é igual a segurança pessoal e a propriedade. Por conclusão, a constituição dos E.U.A. tem por objetivo defender a segurança pessoal e os direitos de propriedade da minoria contra a maioria.

O remédio adequado para as facções seria um governo federativo e representativo (um governo muito inspirado em Montesquieu). Segundo os federalistas, esse governo manteria a forma e o espírito do governo popular. A representação assume no Federalista os objetivos que vimos em Montesquieu: trazer a virtude para a centralidade do núcleo argumentativo da filosofia política, ou seja, o que deve conduzir o governo aos seus fins é a virtude. Isso é feito através de um número pequeno de representantes, afastando o povo das decisões do governo. Os federalistas chamam isso de "depurar" e "aumentar" o espírito público.

Bentes (2006) trouxe no seu trabalho a irretocável análise de que há nesta forma de governo a transformação da cidadania (cidadania ativa), que os gregos conheciam e que Rousseau tanto defendeu no Contrato Social (1973), em ação cívica ocasional, criando, ao mesmo tempo, uma classe política profissional. De acordo com esta análise, com a qual concordamos, o Federalista (HAMILTON et al., 1973) traz uma retórica pseudodemocrática e transforma o conceito de soberania popular, levado tão às últimas consequências por Rousseau e que, a nosso ver, era a tendência da filosofia política moderna entre os séculos XVII e XVIII, em um conceito puramente formal. 
O legislativo no Federalista é distanciado do povo a tal ponto que os autores chegam a afirmar que a proximidade dos representantes dos interesses locais afastaria os mesmos dos interesses gerais da nação, precisando, por conseguinte, haver uma certa distância entre o poder e o povo, de forma que os representantes não sofram uma pressão direta daqueles que o elegeram. Além disso, eles defendem um legislativo bicameral, remontando a Montesquieu. A diferença é que em Montesquieu essa câmara seria para os nobres e para os federalistas para políticos que passariam seis anos no cargo, tendo tempo para estudar mais a fundo os assuntos da nação. Em suma, o Senado é o repositório da virtude no governo (como, aliás, não deixava de ser em Montesquieu), formando uma classe especial de políticos profissionais. Aliás, só os da Câmara dos Representantes seriam eleitos diretamente pelo povo (mandato de dois anos e muito distanciados da vontade do povo), o Senado e o presidente, como vimos, seriam eleitos indiretamente (senadores por seis anos).

Em um determinado ponto, os federalistas afirmam que o único objetivo do governo, ou seja, o seu fim, seria a felicidade do povo. Entendemos que há uma diferença abissal entre bem comum e felicidade do povo. Os federalistas chegam a utilizar o termo "bem comum", mas esse bem comum, como vimos logo acima, equivale à proteção pessoal e aos direitos de propriedade. Logo, felicidade do povo, para eles, é simplesmente proteção pessoal e direitos de propriedade da minoria contra a maioria. A felicidade diz respeito perfeitamente ao indivíduo alheado das questões públicas, formando um abismo entre o indivíduo norte-americano e o cidadão da pólis grega.

De acordo com Bentes (2006), o Federalista rompe com a teoria política clássica, no sentido do engajamento do cidadão nas decisões e nos debates públicos, e coloca o cidadão na posição de um mero realizador do seu interesse particular. O homem seria um ser simplesmente guiado por suas paixões e que, apenas de forma secundária, participa da sociedade com uma calculadora de custos e benefícios. A visão de Rousseau (1973) do cidadão imerso nos negócios públicos dá lugar ao sujeito que meramente articula com os outros interesses convergentes. Bentes (2006) afirma a substituição da virtude pelo comércio, retirando do homem a ligação concreta que o mesmo possuía com o seu meio de vida e sua propriedade, que é a própria substituição da racionalidade, que se refletia em sua participação política, pelas paixões. "Decai o homem político e ascende o auto-interesse” (BENTES, p. 45).

Por fim, concluímos que o quantum de poder do povo sob a constituição defendida pelos federalistas (HAMILTON et al., 1973) é totalmente nulo, mesmo o povo elegendo deputados para a Câmara dos Representantes. A emanação do poder vindo do povo não passa de uma ilusão, um artifício de retórica pseudodemocrática para criar um simulacro de legitimidade. O povo, nesta forma de governo, não tem a menor possibilidade de ditar os rumos deste. Pelo contrário, o Federalista é um marco do surgimento de uma classe de políticos profissionais e da substituição do cidadão pelo homem ligado ao comércio e à sua vida privada. Em relação ao sistema representativo, os federalistas repetem a argumentação de Montesquieu (1979), de que o povo não teria condições de tratar dos negócios públicos (não teria virtude), dando ênfase, desta forma, ao argumento de que o povo é sempre um potencial tirano de si mesmo (argumento da tirania do povo). A vontade do povo deve ser representada por aqueles que possuem a virtude, é este o argumento que, tanto em Montesquieu (1979) quanto no Federalista (HAMILTON et al., 1973), distancia o povo do poder e gera a crise de representação da qual Singer (2000) falou. 


\section{REFERÊNCIAS}

BENTES, F. (2006). A Separação de Poderes na Constituição dos Estados Unidos: Da Revolução Americana ao constitucionalismo de Jefferson, Madison e Hamilton. Rio de Janeiro. 96p.. Dissertação (Mestrado em Direito). PUC-Rio.

GIDDENS, A. (1999). Mundo em Descontrole. Rio de Janeiro: Record, 2000.

HAMILTON, A. et al. (1788) O Federalista. São Paulo: Abril Cultural, 1973. Os Pensadores.

LOCKE, J. (1689) Segundo Tratado Sobre o Governo Civil. Petrópolis: Vozes, 2001.

MAGGS, G. (2007). "A Concise Guide to the Federalist Papers as a Source of the Original Meaning of the United States Constitution”. George Washington University Law School Public Research Paper: 258, 801-847.

MILLER, J. (1988) “The Ghostly Body Politic: The Federalist Papers and popular sovereignty”. Political Theory: 16/1, 99-119.

MONTESQUIEU. (1748). Do Espírito das Leis. São Paulo: Abril Cultural, 1979. Os Pensadores.

PEACOCK, A. (2010). How to Read the Federalist Papers. Washington, DC: The Heritage Foundation, 2010.

PIRES, Felipe. (2015). O Povo no Poder: Virtude e vontade do Estado legítimo de Jean-Jacques Rousseau. Recife: [s.n,]. Dissertação de mestrado pela Universidade Federal de Pernambuco.

ROUSSEAU, J-J. (1762). Do Contrato Social ou Princípios do Direito Político. São Paulo: Abril Cultural, 1973. Os Pensadores.

SINGER, A. (2000) “Rousseau e o Federalista: Pontos de aproximação”. Lua Nova: 51, 41-50.

Artigo recebido em: 31 de maio de 2020

Artigo aceito em: 03 de julho de 2020 